\title{
Injury Pattern Of The Patients Attending The Emergency Department In Manikgonj General Hospital
}

\author{
Altaf Hossain Khan', Md. Iftekhar Hasan Khan', Mainul Hossain Khan ${ }^{3}$
}

\begin{abstract}
A retrospective study on injury pattem of cases attending the emrengency department of Manikgonj General Hospital was conducted from March to May 1990. The study population comprising of 994 injured patients attending the emergengy department of the bospital daring the period of October to December 1989. It was found that bigbest $(52.52 \%)$ number of injured cases was victim of mad traffic accidents and male $(89.46 \%)$ out numbered female $(10.54 \%)$. The most afferted age group was 25.34 years. The most common site of injury was lower limb and next was upper limb.
\end{abstract}

\section{Introduction}

A great number of unfortunate and innocent people of our country are becoming disabled duc to accidents by cyclone and flood. Death rate from accidental injuries are also high for want of prompt and efficient emergency health service and facilities. Adequate trained personnel in emergency department might reduce death rate and number of disabled.

The incident of trauma cases is on the rise all over the world. Now this has assumed epidemic proportions among all types of accidents in home, in place of work at play and elsewhere those caused by motor vehicles claims largest toll of life tend to be the most serious. A terrible penalty of mortality is being paid due to integration of motor vehicles into the luxury of modern life. A WHO survey made between 1960 and 1972 in Hong Kong, Jamaica, Jordan and Malaysia recorded decrease in death from infectious discases and a steady increase in road accident fatalitics.

Accidents today are among the lcading causes of

1. Associate Professor, Dept. of Community Medicine. Holy Family Red Crescent Medical College

2. Surveillance Medical Officer, World Healıh Organization, Nawgaon

3. Assistant Professor, Dept. of Community Medicine, Holy Family Red Crescent Medical College death. The number of minor as well as major injuries and the human sufferings the economic loss duc to disabilities caused by accident is unestimate able. Thus while medical science has conquered the ravages of many diseases accidents have become a new Epidemic of public health importance calling for cqual efforts for control and prevention. The natures of accident vary from country to country. In Bangladesh road traffic accident is identificd as a great killer and disablers of mankind. To prevent mortality among the injured, a high standard of emergency department is virtually important.

\section{Observations and Results}

\begin{tabular}{|c|c|c|c|c|c|c|}
\hline $\begin{array}{l}\text { Causes of } \\
\text { injury }\end{array}$ & Mala & $\begin{array}{l}\text { Perc: } \\
\text { entage }\end{array}$ & Female & $\begin{array}{l}\text { Pers- } \\
\text { entage }\end{array}$ & Total & $\begin{array}{l}\text { Pero } \\
\text { entaga }\end{array}$ \\
\hline $\begin{array}{l}\text { Road } \\
\text { talic } \\
\text { scosident }\end{array}$ & 467 & $59.90 \%$ & 55 & $25.82 \%$ & 522 & $5252 \%$ \\
\hline $\begin{array}{l}\text { Mochinery } \\
\text { accidant }\end{array}$ & 140 & $17.93 \%$ & 59 & $27.70 \%$ & 199 & $20,02 \%$ \\
\hline Acsaut & 100 & $1280 \%$ & 24 & $11.27 \%$ & 124 & $12.47 \%$ \\
\hline Fal & 34 & $4.35 \%$ & 23 & $10.80 \%$ & 57 & $5.73 \%$ \\
\hline Eum & 10 & $1.28 \%$ & 35 & $16.43 \%$ & 45 & $4.53 \%$ \\
\hline Otvers & 30 & $384 \%$ & 17 & $7.98 \%$ & 47 & $4.73 \%$ \\
\hline Total & 721 & $100 \%$ & 213 & $100 \%$ & 994 & $100 \%$ \\
\hline
\end{tabular}

Table I: Distribution of iniury pattern by cause and sex. 
Table-I shows that out of total male paticnt road traffic accident $(59.80 \%)$ was the highest and burn (1.28\%) was the lowest. Among total female patient machinery accident $(27.70 \%)$ was the highest and fall $(10.80 \%$ ) was the lowest. It is revealed that road traffic accident $(52.52 \%)$ was the most common causes of injury. Machinery accident was the $2^{\text {nd }}$ common cause.

\begin{tabular}{lcc}
\hline Type of Injury & Number of cases & Percentage \\
\hline Laceration & 245 & $24.65 \%$ \\
\hline Abrasion & 234 & $23.54 \%$ \\
\hline Simple Fracture & 155 & $15.60 \%$ \\
\hline Incised & 110 & $11.07 \%$ \\
\hline Compound Fracture & 84 & $8.45 \%$ \\
\hline Punctured & 55 & $5.53 \%$ \\
\hline Head injury & 07 & $0.70 \%$ \\
\hline Others & 104 & $10.46 \%$ \\
\hline Total & 994 & $100 \%$ \\
\hline
\end{tabular}

Table Il: Distribution of injury by Type

The table II shows the percentage of laceration $(24.65 \%)$ was highest. Abrasion was the next $(23.55 \%)$ followed by simple fracture $(15.60 \%)$.

\section{Methodology}

This was a retrospective study carried out at the General Hospital, Manikganj during the period of March 1990 to May 1990. The general hospital was selected as a place of study because it is situated by the side of highway and surrounded by factories. The study subjects were the patients attending the emergency department from October 1989 to December 1989 and the total numbers of cases were 994. All information was collected from emergency and admission registers of the hospital.

\section{Discussion}

The incidence rate of road traffic accident is very high in Bangladesh. This study was carried out to find out the injury patterns of road traffic accidents of reported patients in nearby road- side hospital like Manikgonj General Hospital. Bari $S A$ conducted a retrospective study on 440 accident cases in emergency department of Rajshahi medical college hospital of which $83 \%$ were male and $16.7 \%$ werc female and road traffic accident $(47.9 \%)$ was on the top of the list. Parker SE in his topic accident pointed out that in India in 1978 death reported from accident numbered 118594 of which road accident were 17600 . It was revealed that most common causc of injury was road accident. They numbered 522 representing $52.52 \%$. They were in either knocked down by cars, buses, trucks and motorbikes. Judith $A$ et al conducted a study on pedestrian in jury in Canada and observed that pedestrian injury events are subject to motor vchicle accident. In 5 years duration 2972 pedestrians were killed.

If we look at pattern of injury cases we sec that lacerated injury was the highest $(24.65 \%)$ and abrasion was the second common type of injury $(23.55 \%)$. Next rype of injury was fracture. Simple fracture was $15.60 \%$ and compound fracture was $8.45 \%$. Susan P Barker MPH conducted study on injuries and found that injuries are the most serious and preventable of all major health problems. The second common cause of injury was machinery accident They numbered 199 out of 994 . Most of the injury cases were lacerated injury. BB Summer et al conducted a study on injury in USA and found that injury is the foremost public health problem. The causes of accident must be determined by survey so that appropriate measure can be taken for prevention and treatment of injury cases.

\section{Conclusion}

Laccration was highest among the casualties. Majority of the cases were rickshaw-pullers. From this study, it can be concluded that most of the injured cases attended Manikgonj General Hospital were road traffic accidents as it is located nearcr to highway.

Emergency department of all the hospitals should be provided with well-trained Medical 
Officer and fortified with all necessary instruments and facilities. Improvement of road condition, imposition speed limits, marking of danger points, proper illumination and presence of police on the road should be ensured.

\section{References}

1. Park JE, Park K. Textbook of Preventive and Social Medicine Pub: Banarsidas Bhanot, Jabalpur, India; 11th Edition, (1986) 309-310

2. Summer BB, Mintz ER, Brown PL. The British Journal of Accident Surgery (1987);18: 225

3. Judith A et al, Journal of Trauma (1989) 29: 741 Susan P Baker. The neglected epidemic. Journal Of Trauma ; (1989) 27: 343

4. Bari S A. An Epidemiological study of accidents. Bangladesh Medical Journal (1984) 17:12-16 